\title{
Die dilemma van die literêre vorm van Openbaring 2 en 3
}

\section{'n Evaluering van Aune en Shea se voorgestelde teorieë}

\author{
A.H. Grové \\ Gereformeerde Kerk Klerksdorp-Noord \\ KLERKSDORP
}

\begin{abstract}
The aim of this study is to investigate the still unsatisfactorily addressed problem of the literary form of Revelation 2 and 3. In this article formulations and elements in the Old Testament prophecies (as pointed out by Aune, 1983) as well as the proposed definition of apocalyptic genre by Aune (1986) are applied. In this article Aune's definition of apocalyptic literalure, as applied by him to Revelation in rotality, is applied specifically to Revelation 2 and 3. At the same time the findings of Aune (1990) that the seven pericopae have the form of royal edicts, as well as the conclusion of Shea (1983) that these messages have a covenantal form, are evaluated. The conclusion arrived at in this study points to the following: formally these seven messages are prophetic apocalypses as well as royal edicts. They display neither the form of epistles nor of Hittite vassals. As far as their content is concerned, they have a prophetic character which corresponds to the Old Testament prophecics. Each message in Revelation 2 and 3 functions as a book of comfort, conveys the idea of Christ as King, and states the promises of God to the seven churches. The messages in Revelation 2 and 3 do not represent a single typical literary form of antiquity: it rather displays a combination of literary forms - and this should be taken into account in the interpretation of Revelation 2 and 3.
\end{abstract}

\section{Inleiding}

\subsection{Probleemstelling}

Verskillende navorsingsresultate oor die literêre vorm van Openbaring het al die lig gesien. ${ }^{1}$ Daar bestaan egter ' $n$ leemte oor navorsing in verband met die literêre vorm van Openbaring 2 en 3 omdat navorsers nie eenstemmig is oor die literêre

I Vergelyk in hierdie verband Collins, J.J (1979), Aune (1986) en Hellholm (1986) 
vorm van Openbaring 2 en 3 nie. Die sewe perikope in Openbaring 2 en 3 vertoon nie die patroon van enige antieke literêre vorm nie (Aune, 1990:195).

Die volgende voorstelle is al gemaak om die literêre vorm te probeer omskryf: "So-called letters" (Swete, 1906:23; Corsini, 1983:81), "these chapters ... are addressed to the church in the apostolic style" (Lilje, 1955:66), "seven woorden" (Van der Waal, 1971:166), "special messages" (Ladd, 1972:36), "seven messages" (Collins, A.Y., 1979:70). Shea (1983:76) beredeneer die feit dat Openbaring 2 en 3 'n "covenantal formulary" vertoon; "prophetic messages ... closer to the judgement tradition of the prophets" (Muse, 1986:147,160-161), "serve more or less as "cover-letters' for the rest of the work" (Kirby, 1988:199); "royal edict" (Aune, 1990:192), "briefboodskappe” (Du Rand, 1990:268).

Die uiteenlopendheid van bogenoemde standpunte vra besinning oor die literêre vorm $^{2}$ van Openbaring 2 en 3. 'n Vraag wat na vore kom, is of Openbaring 2 en 3 tot dieselfde genre hoort as Openbaring, of dien Openbaring as 'gasheer' 3 vir Openbaring 2 en 3 - 'n siening wat impliseer dat Openbaring 2 en 3 tot 'n eie genre behoort? Ondanks verskille is genoemde navorsers wel eenstemmig dat Openbaring 2 en 3 'n eie literêre vorm binne die groter geheel van Openbaring het.

\subsection{Doel}

Of Openbaring 2 en 3 tot 'n eiesoortige (nie noodwendig 'n selfstandige) literêre vorm behoort, word in hierdie artikel ondersoek. Hierdie hipotese word binne die konteks van die volgende reeds bestaande bevindings van Aune (1983, 1986, 1990) en Shea (1983) geëvalueer. Aune en Shea se voorstel vir die literêre vorm enersyds van Openbaring in sy geheel en andersyds van Openbaring 2 en 3 word vervolgens ondersoek:

* Die profetiese karakter van Openbaring 2 en 3 in die lig van die Ou-Testamentiese profesieë (Aune, 1983:89-97, 275-279) (vgl. §2);

* Die model van Aune (1986) vir Openbaring in sy geheel: 'n voorgestelde definisie vir apokaliptiese literêre vorm (vgl. §3);

* Openbaring 2 en 3 as ' $n$ koninklike edik (Aune, 1990) (vgl. §4);

* Openbaring 2 en 3 in die vorm van 'n verbond (Shea, 1983) (vgl. §5).

2 Onder literêre vorm word in hierdie artikel dieselfde as genre verstaan, terwyl vorm verwys na die patroon wat 'n geskrif vertoon, soos blyk uit elemente soos die inleiding, slot, klimaks, die (eerste of tweede) persoon waarin dit geskryf is.

3 Aune (1986:80) praat van “'host' or 'inclusio' genres” 


\section{Profetiese elemente en literêre vorm}

Aune (1983:89-97, 275-279) wys op verskillende tipiese formulerings en elemente wat by die Ou-Testamentiese profete voorkom, en hy maak ook 'n vergelyking tussen Openbaring 2 en 3 en die Ou-Testamentiese profete. In die lig van Aune se bevinding word vervolgens 'n evaluering en uiteensetting daarvan gegee.

\subsection{Ou-Testamentiese profetiese formulerings en elemente}

Skryfopdrag en geadresseerdes: Die sewe perikope in Openbaring 2 en 3 begin gelykluidend met ' $n$ skryfopdrag aan Johannes en die geadresseerdes word ook genoem (Op. 2:1, 8, 12, 18; 3:1, 7, 14). Sodanige skryfopdrag en die vermelding van die geadresseerdes kom enkele kere by die Ou-Testamentiese profete voor (vgl. Jes. 8:1; 30:8; Hag. 2:2).

Die boodskapper-met-'n-opdrag-formule: In die Ou-Testamentiese profete kom die frase "so sê die Here" (כָה אָמר יחודה) dikwels as tipiese profetiese formule voor (Jer. 19:1; Eseg. 25:12). Aan elkeen van die sewe gemeentes maak

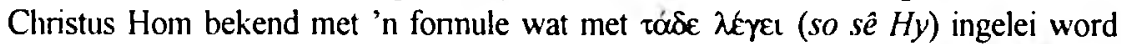

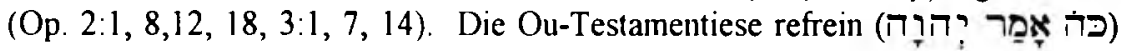

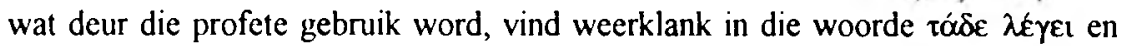
word daarmee "ingeskakel in die ry van erkende profete" (Groenewald, 1986:48; vgl. Kittel, 1969:109; Aune, 1990:1854). In die Boodskappe kom God self deur Johannes aan die woord.

Gesagsoproep: 'n Gesagsoproep kom in die profete dikwels aan die einde van 'n uitspraak voor as "hoor die woord van die Here" (Jer. 29:20; 42:15; Eseg. 13:2; Amos 7:16). Al sewe boodskappe in Openbaring 2 en 3 het aan die einde die gesagsoproep: "Elkeen wat kan hoor, moet luister na wat die Gees vir die gemeentes sê."

Positiewe/negatiewe evaluering: In die profete vind ons 'n positiewe (Dan. $1: 17 ; 6: 11$ ) en negatiewe evaluering (Jes. 1:3; 65:12; Hag. 1:9) van die volk van God en van individuele gelowiges. Die negatiewe evaluering word soms ook in samehang met 'n veroordeling of aanklag gestel (Hos. 4:1-3; Miga 6:1-2). Soortgelyke positiewe en/of negatiewe evaluerings van die sewe gemeentes deur Christus kom ook in Openbaring 2 en 3 as oi $\delta \alpha$-frases voor (Op. 2:2-4, 8, 13-15, 19, $20 ; 3: 1,2,8,10,15-17)$.

4 Aune (1990:187) wys daarop dat die Hebreeuse frase

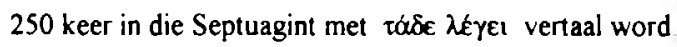


Vermaning: Israel word deur die Here vermaan met die doel om ' $n$ regstelling in hulle lewe te bring (Jes. 1:10-17; Jer. 3:12-13; Amos 4:4-5). Hierdie vermanings neem dikwels die vorm aan van 'n oproep tot bekering, verbetering en bemoediging (Jes. 31:6; 43:1, 5, Jer. 25:5; Eseg. 18:30; Sag. 9:12; Mal. 4:4). Sodanige oproep tot bekering word dikwels in Openbaring 2 en 3 gevind (Op. 2:5, 16,$21 ; 3: 3,19 ; \S 3.3 .3$ ).

Heils- en onheilsbelofte: Die Here maak aan Israel heilsbeloftes (1 Kon. 11:30, 31; Jes. 43:1-4; Jer. 31:34; Amos 9:11-15; Sag. 1:17) asook onheilsbeloftes (Jer. 17:4; Amos 7:1-9). Aan die einde van elkeen van die perikope in Openbaring 2 en 3 staan 'n oorwinnaarsbelofte opgeteken (Op. 2:7, 11, 17, 26, 27; 3:5, 12, 21). Onheilsbeloftes word in Openbaring 2 en 3 in die vorm van dreigemente aangetref (Op. 2: 5, 10, 16, 22, 23; 3:16).

Deelgenootskap: Die profete se deelgenootskap op verskillende vlakke met die volk van God kom enkele kere in die Ou Testament voor (bv. Jes. 6:5; Hos. 2:1, 3). 5 Van Johannes word eweneens gesê dat hy met betrekking tot drie aspekte deel het aan die kerk: verdrukking, koninkryk en volharding (Op. 1:9). Openbaring 1:9 werp lig op die funksie van Openbaring. Uit Openbaring 1:9 blyk dat Openbaring vir die kerk troosboek in verdrukking is, koningsboek is wat die regering van Christus in sy kerk beskryf en belofteboek is wat 'n eskatologiese perspektief aan die kerk wil gee (Mounce, 1980:74-75; Coetzee, 1990:265-266). Openbaring 2 en 3 funksioneer eweneens as koningsboek, belofteboek en troosboek (Grové, 1989:19-21).

Die voorkoms van koninkryk, volharding en verdrukking in Openbaring 2 en 3 kan soos volg getabuleer word:

\begin{tabular}{|c|c|c|c|}
\hline Gemeente & Koninkryk & Volharding & Verdrukking \\
\hline Efese & $\begin{array}{l}\text { Christus regeer } \\
(2: 1)\end{array}$ & $\begin{array}{l}\text { Volharding } \\
(2: 2)\end{array}$ & $\begin{array}{l}\text { Arbeid } \\
(2: 2)\end{array}$ \\
\hline Smima & $\begin{array}{l}\text { Christus heers oor dood } \\
(2: 8)\end{array}$ & $\begin{array}{l}\text { Aangespoor om getrou } \\
\text { te wees tot } \\
\text { die dood }(2: 10)\end{array}$ & $\begin{array}{l}\text { Verdrukking } \\
(2: 9)\end{array}$ \\
\hline Pergamum & $\begin{array}{l}\text { Christus regeer deur } \\
\text { swaard }(2: 12)\end{array}$ & $\begin{array}{l}\text { Getrou gebly } \\
(2: 13)\end{array}$ & $\begin{array}{l}\text { Antipas gedood } \\
(2: 13)\end{array}$ \\
\hline Tiatire & $\begin{array}{l}\text { Jesus regeer as regter } \\
\text { en oorwinnaar } \\
(2: 18,27)\end{array}$ & $\begin{array}{l}\text { Volharding } \\
(2: 19,25)\end{array}$ & $\begin{array}{l}\text { Swaar lyding } \\
(2: 22)\end{array}$ \\
\hline
\end{tabular}

5 Hierdie faset van die Ou-Testamentiese profesie word nie deur Aune (1990) beredeneer nie 


$\begin{array}{llll}\text { Sardis } & \begin{array}{l}\text { Jesus regeer deur sy } \\ \text { Gees }(3: 1)\end{array} & \begin{array}{l}\text { Gemeente is dood, geen } \\ \text { volharding }\end{array} & \begin{array}{l}\text { Gemeente is dood; nog } \\ \text { meer gaan sterf }(3: 1,2)\end{array} \\ \text { Filadelfia } & \begin{array}{l}\text { Die Dawidskoning } \\ \text { heers }(3: 7)\end{array} & \begin{array}{l}\text { Boodskap van } \\ \text { volharding }(3: 10)\end{array} & \begin{array}{l}\text { Bedreiging van Satan } \\ (3: 9)\end{array} \\ \text { Laodisea } & \begin{array}{l}\text { Kerk heers saam met } \\ \text { Christus }\end{array} & \begin{array}{l}\text { Gemeente is lou, } \\ \text { geen volharding (3:16) }\end{array} & \begin{array}{l}\text { Verdrukking/ellende, } \\ \text { lewe in weelde (Matt. } \\ 12: 22 ; \text { Op. 3:17) }\end{array}\end{array}$

\subsection{Samevatting van die profetiese elemente in Openbaring 2 en $3^{6}$}

* Skryfopdrag en geadresseerdes: 2:1a, 8a, 12a, 18a; 3:1a, 7a, 14a.

* Boodskapper/opdragformule: 2:1b, 8b, 12b, 18b, 3:1b, 7b, 14b.

* Positiewe evaluering: $2: 2-3,6.9 .13 .19 .24-25 ; 3: 4,8,17-19$.

* Negatiewe evaluering: $2: 4-5,20-23 ; 3: 1 c-3 c, 9,15-16$.

* Oproep tot bekering/korrektiewe optrede: $2: 4-5,14-16,20-23 ; 3: 1 \mathrm{c}-3 \mathrm{c}$, 17-19.

* Bemoediging: 2:10.

* Gesagsoproep: 2:7a, 11a, 17a, 29; 3:6, 13, 22.

* Heilsbelofte: 2:b, 10b, 11b, 17b, 27-28, 3:5, 12, 20-21.

* Onheilsbelofte: $2: 10-11$

\subsection{Gevolgtrekking}

Aangesien die profetiese elemente volgens Aune (1983) se kriterium (\$2.1) in Openbaring 2 en 3 figureer ( $\$ 2.2$ ), word die volgende gevolgtrekking gemaak: In elkeen van die sewe perikope in Openbaring 2 en 3 kom profetiese elemente voor wat inhoud, vorm ${ }^{7}$ en funksie betref. Elkeen van die sewe perikope sluit nou aan by die Ou-Testamentiese profetiese tradisie in die lig van Openbaring 1:3 en 22:7,

6 Roberts (1988:23) wys tereg daarop dat die sewe boodskappe nie rigied en stereotiep gekonstrueer is nie Daar word derhalwe afgewyk van die vae, simplistiese en homogene indeling van Aune (1983:275) en vele ander navorsers van die perikope in Openbaring 2 en 3, naamlik (1) inleiding, (2) middeldeel en (3) dubbele gevolgtrekking Vir 'n weergawe van die eie struktuur van elke perikoop in Openbaring 2 en 3 vergelyk Grové (1992:18-19, 56, 83-84, 127, 164, 206-208, 250-251)

7 Met verwysing na 2 Kronieke 21:12-15, Jeremia 6:17-23 en 29:1-23 meen Müler (1983:601) dat Openbaring 2 en 3 "in der literarische Formtradition des Prophetenbriefes" staan. Alhoewel hierdie resultaat strook met dié van Aune (1983) is dit nie genoegsaam beredeneer nie Müler gee myns insiens nie genoegsame aandag aan die inhoud van Openbaring 2 en 3 nie 
10,18 en 19 waar na Openbaring verwys word as 'n profesie, en die feit dat dit funksioneer as troosboek, koningsboek en belofteboek (Op. 1:9).

\section{Apokaliptiese elemente en literêre vorm}

Aune $(1986)^{8}$ bespreek die literêre vorm van Openbaring met inagneming van ander apokaliptiese literatuur (soos die Christelike, Joodse, Grieks-Romeinse, Grieks-Egiptiese, Iranese en Grieks-Persiese) en definieer die apokalitiese literêre vorm soos volg:

(1) Form: an apocalypse is a prose narrative, in autobiographical form, of revelatory visions experienced by the author, so constructed that the central revelatory message constitutes a literary climax, and framed by a narrative of the circumstances surrounding the revelatory experience(s). (2) Content: the communication of a transcendent, often eschatological, perspective on human experience. (3) Function: (a) to legitimate the transcendent authorization of the message, (b) by mediating a new actualization of the original revelatory experience through literary devices, structures and imagery, which function to 'conceal' the message which the text 'reveals,' so that (c) the recipients of the message will be encouraged to modify their cognitive and behavioral stance in conformity with transcendent perspectives (Aune, 1986:86-87).

Aune (1986) toon aan dat Openbaring in sy geheel aan hierdie definisie voldoen. Hy toon egter nie aan dat hierdie definisie spesifiek vir Openbaring 2 en 3 geldig is nie. Indien dit aangetoon kan word, kan gesê word dat Openbaring 2 en 3 tot die apokaliptiese literêre vorm behoort. Openbaring 2 en 3 word vervolgens geevalueer aan die hand van Aune (1986) se definisie.

\subsection{Vorm}

Drie sake word onder vorm bespreek: 'n apokalips (1) toon 'n dominante eerstepersoonstyl, (2) het 'n sentrale tema of boodskap en die tema val saam met die literêre klimaks van die geskrif, en (3) is binne 'n sekere sosio-historiese konteks geskryf.

- Eerstepersoonstyl: Openbaring is in die eerstepersoonstyl geskryf met Johannes as onderwerp (Op. 1:8-20; 4:1; 5:1; 6:1; ens.). In Openbaring 2 en $3 \mathrm{kom}$ nie Johannes nie, maar Christus in die eerstepersoonstyl aan die

8 Die artikels van Collins, J J. (1979), Hellholm (1986) en Aune (1986) kan beskou word as standaardwerke in verband met navorsing oor die literêre vorm van Openbaring. Die artikel van Aune (1986) evalueer en verdiskonteer dié van Collins, J.J. en Hellholm. Die definisie van Aune vir 'n apokalips bou voort op en sistematiseer die definisies van Collins, J.J. (1979:9) en Hellholm (1986:26-27) 
woord (oi $\delta \alpha$ in Op. $2: 2,9,13,19 ; 3: 1,8,15$ ). Elke perikoop in Openbaring 2 en 3 voldoen aan Aune se definisie van 1986.

- Sentrale tema en klimaks: Apokaliptiese geskrifte (vgl. byvoorbeeld Herder van Hermas, I Henog, 2 Barug, 4 Esra en Openbaring 4:1-22:5) het volgens Aune (1986) 'n klimaks wat saamval met 'n sentrale tema. Dieselfde tendens word op mikrovlak in Openbaring 2 en 3 gevind: elke perikoop het 'n eie gedagte-opbou met 'n sentrale tema wat binne die perikoop in 'n klimaks of fokuskomponent ontvou, soos hieronder bespreek.

- Efese (2:1-7): Die sentrale tema van die teenwoordigheid van Christus by sy kerk, wat in die selfidentifikasie (2:1) gestel word, kom klimakties in die belofte na vore.

- Smirna (2:8-11): Die oorwinningstema wat in die selfidentifikasie (2:8b) opgeneem is, vind uitdruklik weerklank in die belofte dat die gemeente oorwinnaars oor die dood sal wees $(2: 10 \mathrm{~d}, 11 \mathrm{~b})$.

- Pergamum (2:12-17): Die sonde van sinkretisme wil Christus uit hulle midde weer, en derhalwe maak Hy Hom aan hulle bekend as die Een wat die skerp tweesnydende swaard het $(2: 12 b)$. Hy rig ook 'n dringende dreigement $(2: 16)$ aan hulle adres om enige sinkretisme uit hulle midde te weer. Die aspek van geen vermenging wat in die selfidentifikasie na vore kom en 'n deurlopende toepassing in die hele perikoop vind, word in die dreigement op die spits gedryf.

- Tiatira (2:18-29): "Die vrou Isebel" het die gemeente verlei (2:20-21). In sy kerk is Christus Regter en Heerser wat die beginsel van geen kompromie met afgodiese praktyke en leerstellings handhaaf. Dié tema van geen kompromie kom deurgaans in die perikoop voor.

- Sardis (3:1-6): Die ontbrekende eskatologiese verwagting wat daar by die gemeente was, word as 'n deurlopende motief in 3:1-6 gevind deur woorde en sinsnedes wat eskatologiese trekke het. Die werksaamheid van Christus om 'n eskatologiese verwagting by die gelowige te bewerkstellig, vind op 'n besondere wyse neerslag in die oproep tot bekering (3:3-4)

- Filadelfia (3:7-13): Die gemeente in Filadelfia het op drie fronte onstabiliteit belewe. Van buite is die gemeente gekonfronteer met die Jode wat vanuit die leuen in hulle midde werksaam was (3:9). Van binne het die gemeente self min krag gehad (3:8). Die gemeente was fisies in die streek wat deur aardbewings geteister is. Aan diè gemeente bring Christus die perspektief van permanensie in hulle bestaan as kerk ondanks watter onstabiliteit hulle ook al ervaar.

- Laodisea (3:14-22): Die Laodiseagemeente was ontrou en oneffektief in die uitoefening van hulle roeping. Hulle was vals en het ' $n$ hedegerigte en egosentriese visie ten opsigte van hulle bestaan gehad. Christus dui egter aan waarin die regstelling hiervan moet bestaan: Christus moet die sentrum van 
hulle bestaan as gemeente uitmaak (3:18). Die gemeente in Laodisea vind ook hulle enigste bestaansmoontlikheid in Christus. Christus wil 'n Christosentriese en eskatologiese visie by hulle tot stand bring. Deur die korrektiewe optrede van Christus in die gemeente (3:18) wil Hy hê hulle lewe moet die wesenstrek van waarheid hê en nie dié van valsheid nie.

In elke perikoop in Openbaring 2 en 3 is daar 'n korrelasie tussen die fokuskomponent en die sentrale tema.

- Geskryf binne 'n sosio-historiese konteks: Die sosio-historiese konteks van Openbaring word in die algemeen in 1:11 gestel as dié van die sewe gemeentes in Klein-Asië, en in die besonder skryf Johannes dat hy "deel aan die verdrukking en aan die koninkryk en aan die volharding" (1:9) van dié gemeentes. Openbaring 2 en 3 is egter binne 'n spesifieke sosio-historiese konteks geskryf aangesien elkeen van die sewe perikope binne sy eie unieke sosio-historiese omstandighede neerslag vind.

\subsection{Inhoud}

Aune (1986) toon aan dat apokalipse twee inhoudelike kenmerke het: menslike optrede word binne eskatologiese (gerigtheid op eindtyd) en transendentale (van bo en buite die menslike ervaring en bestaan) perspektief belig.

- Die eskatologiese perspektief: In al sewe perikope in Openbaring 2 en 3 word die optrede van die gemeentes vanuit 'n eskatologiese visie na vore gebring, soos blyk uit die bespreking wat volg.

- Efese (2:1-7): Met sy regterhand regeer Christus sy kerk in die hede en tot in ewigheid (2:1b). Ook deur middel van die oproep tot bekering (2:3), in die stelling "Ek kom na jou toe" (2:5) en in die belofte (geformuleer in terme van die motiewe van die boom van die lewe en die Paradys) (2:7) word die optrede en voortbestaan van die gemeente binne eskatologiese konteks geplaas.

- Smirna (2:8-11): As oorwinnaar oor die dood (2:8) is Christus die waarborg van die ewige heil vir sy kerk. Ook in 2:9-11 word die eskatologiese dimensie aan die orde gestel met frases soos "Ek sal julle die lewe as kroon gee" (2:10) en "Dié wat die oorwinning behaal, sal beslis nie deur die tweede dood getref word nie" (2:11).

- Pergamum (2:12-17): Christus het die swaard met die skerp snykante. In die hoedanigheid is $\mathrm{Hy}$ die waarborg vir die ewige bestaan van die kerk $(2: 12,17)$.

- Tiatira (2:18-29): Die eskatologiese motief word geïmpliseer in 2:19 met die term volhard, in 2:23 met die frase "Ek sal elkeen van julle 
straf volgens julle doen en late" en in 2:25 met die opdrag "hou net vas wat julle het totdat Ek kom".

- Sardis (3:1-6): Die hele Boodskap is eskatologies van aard en die sentrale tema van die Boodskap het 'n eskatologiese stempel. Die optrede van die gemeente word grootliks in eskatologiese terme verwoord $(\$ 3.1)$.

- Filadelfia (3:7-13): Met die frases "vashou in die tyd van beproewing wat ... gaan kom", "Ek kom gou" en "Ek sal hom 'n pilaar in die tempel van my God maak" in 3:9-12 word die bestaan van die kerk in 'n eskatologiese raamwerk geplaas.

- Laodisea (3:14-22): Christus maak bemoeienis met dié gemeente wat 'n gebrek aan eskatologiese visie het, om só 'n verwagting by hulle tot stand te bring. Hy stel vir hulle eskatologiese werklikhede in die vooruitsig (3:20-21).

Die sewe perikope in Openbaring 2 en 3 voldoen aan die eis dat die optrede van mense in ' $n$ apokalips bimne 'n eskatologiese kader gestel word (vgl. Aune se definisie van 1986).

- Die transendentale perspektief: Aan elkeen van die sewe gemeentes maak Christus Hom as God bekend: Efese: Altyd- en alomteenwoordige God (2:1b); Smirna: God wat oorwinnaar oor die dood is (2:8b); Pergamum: God wat oordeel (2:12b); Tiatira: Seun van God wat oordeel (2:18b); Sardis: God die Heilige Gees (3:1b); Filadelfia: Almagtige God wat oordeel (3:7b); Laodisea: Skeppergod (3:14b).

In sy hoedanigheid as God gee Christus ' $\mathrm{n}$ evaluering van die doen en late van die gemeentes (vgl. die oi $\delta \alpha$-uitsprake in Op. $2: 2,9,13,19 ; 3: 1,8,15$ ). Openbaring 2 en 3 bied dus ' $n$ transendentale perspektief op die mens. Dié perspektief strook met die definisie van 'n apokalips soos deur Aune (1986) voorgestel.

\subsection{Funksie}

Uit 'n funksionele gesigspunt gesien, word daar volgens Aune (1986) drie aspekte in 'n apokalips na vore gebring: (1) 'n apokalips dra die stempel dat dit wettig is omdat dit van hoër gesag afkomstig is; dit dra transendentale outoriteit; (2) in 'n apokalips word die boodskap 'bedek' wat in die teks 'geopen' word; (3) die ontvangers van die boodskap word opgeroep om hulle gedrag sodanig te verander dat dit ooreenstem met transendentale perspektiewe.

- Wettige transendentale outoriteit: Die funksie van 'n apokalips is om die ontvangers onder die besef te bring dat die boodskap wat hulle ontvang van transendentale oorsprong is, dat dit wettig is en dat dit met transendentale 
outoriteit beklee is. Die sewe Boodskappe in Openbaring 2 en 3 voldoen aan al hierdie vereistes en dra ook 'n profetiese karakter. Dit pas derhalwe in by Aune se definisie van 'n apokalips $(\$ 2.1,3.1,3.2)$.

- Die boodskap 'bedek' wat in die teks 'geopen' word: Volgens Aune (1986:89-90) geld by 'n apokalips in die algemeen dat die oorspronklike ontvanger van die boodskap dié openbaring op sodanige wyse weergee dat sy lesers/ hoorders deel in die ervaring wat hy gehad het toe hy die openbaring van ' $n$ transendentale bron ontvang het. ${ }^{9}$ Die skrywer gee nie bloot dit wat hy ontvang het deur nie, maar hy voorsien sy gehoor van 'n literêre 'voertuig' sodat hulle sy eie openbaringservaring herleef en vir hulleself die openbaringsboodskap aktualiseer. Die skrywer 'bedek' die boodskap en dit word deur die leser/hoorder 'geopen'. Wanneer die boodskap (apokalips) by 'n openbare optrede voorgelees word, word die deelname van die gehoor gemaksimaliseer en langs hierdie weg word die boodskap 'gereaktualiseer' (Aune, 1986:89). Waarskynlik is dit die rede waarom 'n apokalips in simboliese taal aangebied word.

Openbaring 2 en 3 is deurweef met simboliese taal: Efese: Sewe sterre, sewe goue lampe (2:1b), lamp (2:5), eet van die boom van die lewe en paradys (2:7); Smirna: Tien dae (2:10); Pergamum: Skerp swaard met twee snykante $(2: 12 b)$, troon van Satan (2:13), swaard van my mond (2:16), verborge manna en spierwit klippie (2:17); Tiatira: Oë wat soos vuur vlam en voete soos geelkoper $(2: 18 \mathrm{~b})$, ystersepter en kleipotte $(2: 27)$, môrester (2:28); Sardis: Sewe Geeste en sewe sterre $(3: 1 b)$, wit klere $(3: 4,5)$, boek van die lewe $(3: 5)$; Filadelfia: Sleutel van Dawid (3:7b), kroon (3:11), pilaar in tempel van God (3:12); Laodisea: Goud, wit klere en oogsalf $(3: 18)$, troon $(3: 21)$

Deur gebruik te maak van verskillende simbole laat Johannes dus, binne die konteks van Aune (1986) se definisie, sy leser in Openbaring 2 en 3 deel in sy aanvanklike openbaringservaring (Roberts, 1988:23).

- Die oproep om gedrag te verander: Volgens Aune (1986) het apokalipse paranetiese momente met die doel om die lesers/hoorders te bemoedig sodat hulle hulle gedrag in die hede sal verander om in ooreenstemming met transendentale standaarde te wees. Hieraan gemeet, voldoen Openbaring 2 en 3 aan die kriterium vir ' $n$ apokalips, aangesien daar in Openbaring 2 en 3 telkens 'n oproep tot bekering is: Efese (2:5). Smima: Geen oproep tot bekering. Die gemeente kry net lof en aanmoediging van Christus $(2: 9,10)$. Pergamum: (2:14). Tiatira: (2:22). Sardis: (3:3). Filadelfia: Geen oproep tot bekering. Christus evalueer die optrede van die gemeente positief

9 Binne die tradisie van Christelike apokalipse verwys die term ảnokỏ $\lambda$ vభrs in Openbaring 1:1 waarskynlik na die openbaringservaring van die skrywer, eerder as na die literêre vorm van die boek (Aune, 1987:226). 
$(2: 8,10)$. Laodisea: Die korrektiewe optrede van Christus in 3:18 impliseer bekering.

\subsection{Gevolgtrekking}

Elke perikoop in Openbaring 2 en 3 voldoen aan die verskillende onderdele van Aune (1986) se voorgestelde definisie. Langs hierdie weg is gepoog om op ' $n$ gekontroleerde wyse aan te toon dat die perikope in Openbaring 2 en 3 in profeties-apokaliptiese aard het. Dit is egter nie moontlik om te konstateer dat Openbaring 2 en 3 uitsluitlik 'n profetiese en/of apokaliptiese aard het nie, soos blyk uit $\S 4$. Die profeties-apokaliptiese aard ${ }^{10}$ van Openbaring 2 en 3 sowel as die tydsfaset ${ }^{11}$ waarop hierdie twee hoofstukke betrekking het, is nie van ' $n$ ander aard as die res van Openbaring nie.

\section{Koninklike edik}

Aune (1990) het 'n vergelykende studie gemaak van die vorme wat enersyds in Openbaring 2 en 3 en andersyds in buite-Bybelse koninklike edikte voorkom en konkludeer soos volg. "The literary genre or kind to which the seven proclamations belong is that of the royal or imperial edict" (Aune, 1990:183). In hierdie paragraaf word die bevinding van Aune (1990) dat Openbaring 2 en 3 koninklike edikte is, bespreek.

\subsection{Aune (1990) se bevinding}

Aune (1990) se analise van die onderdele van Openbaring 2 en 3 asook sy bevinding met betrekking tot buite-Bybelse koninklike edikte kan soos volg getabuleer word:

10 Die standpunt van Müller $(1983: 600,602)$ dat Openbaring 2 en 3 van "ganz anders gearteten" as die res van Openbaring en "in einer gewissen Spannung au den andersartige Charakter des apokalyptischen Haupteils 4,1-22, 5" staan, kan dus as ongeldig beskou word.

11 Openbaring 1:19 ("wat nou daar is en wat hierna gaan gebeur") word geïnterpreteer as dat dit op sowel Openbaring 2 en 3 as op die res van Openbaring betrekking het. Die frase "wat nou daar is" het nie uitsluitlik op Openbaring 2 en 3 en "wat hiema gaan gebeur" nie net op Openbaring 4-22 betrekking nie (Grové, 1989:2627). In die lig van Openbaring $1: 19$ meen Collins, A.Y. $(1979: 71,72,83)$ myns insiens tereg dat die sewe boodskappe gerig is op die hede, maar haar siening dat dit die fokus van die leser/hoorder primer op die eskatologiese wil rig binne die konteks van dreigemente en beloftes, is waarskynlik ongeldig. 
Onderdele van Openbaring 2 en 3

Onderdele van koninklike edikte

1. ${ }^{12}$ Geadresseerdes (adscriptio)

(2:1a, 8a, 12a, 18a: 3:1a, 7a, 14a)

2. Skryfopdrag

(2:1a, 8a, 12a, 18a; 3:1a, 7a, 14a)

3. Tód $\lambda \hat{\varepsilon} \gamma \varepsilon\llcorner$-formule

$(2: 1 b, 8 b, 12 b, 18 b ; 3: 1 b, 7 b, 14 b)$

4. Selfidentifikasie

$(2: 1 b, 8 b, 12 b, 18 b ; 3: 1 b, 7 b, 14 b)$

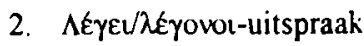

1. Titel van gesagsdraer/skrywer (praescriptio)

3. Voorwoord (prooemium): Seënwense en belangstelling in geadresseerde

5. Beskrywing van die omstandighede van geadresseerdes (oi $\delta \alpha$ - frase; narratio) $(2: 1-4,6,9,131-5,19-20 ; 3: 1 b, 4,8,15)$

4. Stelling (promulgatio). Begin met "Ek maak bekend dat ..."

5. Beskrywing van die stand van sake (narratio)

6. Oproepe / appèlle in die lig narratio (dispositio)

$(2: 5-6,10,16,22-25 ; 3: 2-4,9-11,16-20)$

6. Besluite wat geneem is en opdragte wat gegee is (dispositio)

$7 .{ }^{13}$ Gesagsoproep

$(2: 7,11,17,29 ; 3: 6,13,22)$

8. Oorwinningsbelofte

$(2: 7 b, 11 b, 17,26-27 ; 3: 5,12,21)$

7. Bekragtiging (colloboratio)

\section{Opmerkings}

* Die geadresseerdes en die skryfopdrag van Openbaring 2 en 3 ontbreek in buite-Bybelse koninklike edikte.

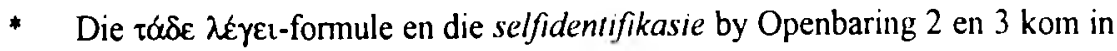
omgekeerde volgorde voor by buite-Bybelse koninklike edikte.

12 Die nommers vooraan toon die volgorde waarin die onderdele in die onderskeie dokumente voorkom.

13 Van die vierde boodskap af kom die gesagsoproep in die laaste posisie voor. 
* Geen gelyksoortige onderdeel as die prooemium soos in die buite-Bybelse koninklike edikte word in Openbaring 2 en 3 gevind nie. Dit kom egter ook nie in alle buite-Bybelse koninklike edikte voor nie.

* Die narratio van die buite-Bybelse koninklike edikte word teruggevind in die oif $\delta$-frase van Openbaring 2 en 3.

* Die dispositio van die buite-Bybelse koninklike edikte word inhoudelik geëggo in die dispositio van Openbaring 2 en 3. Formulerings verskil egter. Gewoonlik word die buite-Bybelse koninklike edikte ingelei met "Ek beveel dat ...", terwyl daar in Openbaring 2 en 3 op gevarieerde wyse oproepe

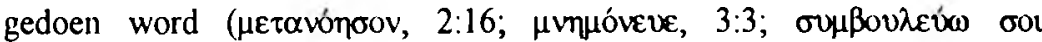
$\dot{\alpha} \gamma o p \alpha ́ \alpha \alpha \mathbf{\alpha}, 3: 18)$.

* Die gesagsoproepe in Openbaring 2 en 3 vind nie 'n teëbeeld in die buiteBybelse koninklike edikte nie.

* Die oorwinnaarsbeloftes van Openbaring 2 en 3 kom ooreen met die bekragtigings van die buite-Bybelse koninklike edikte (Aune, 1990:183-203).

\subsection{Evaluering van Aune (1990) se bevinding}

Die gevolgtrekking van Aune (1990) dat Openbaring 2 en 3 tot die literêre vorm van die koninklike edik behoort, berus grootliks op formele ooreenkomste tussen Openbaring 2 en 3 en buite-Bybelse koninklike edikte. Inhoudelike detailgegewens asook die gedagte-opbou van Openbaring 2 en 3 is nie verdiskonteer nie Die koninklike karakter van Openbaring 2 en 3 wat die gesag van Christus aan die orde stel, word wel deur Aune (1990) onderstreep. Aspekte wat egter nie in hierdie vergelykende studie verreken is nie, is die ekklesiologiese, eskatologiese, juridiese, antitetiese en Christosentriese aspekte wat in Openbaring 2 en 3 aanwesig is (Grove, 1992:280-294). Hierdie aspekte is van belang om op ' $n$ gebalanseerde wyse die probleem van literêre vorm van Openbaring 2 en 3 te omskryf en om die funksie van die geskrifte in Openbaring 2 en 3 te beskryf.

Om Openbaring 2 en 3 as koninklike edikte te sien, is nie strydig met die feit dat dit ook profeties-apokalipties is nie. Gemengde genres kom wel in die Skrif voor. ${ }^{14}$

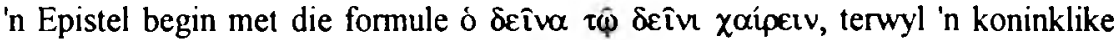

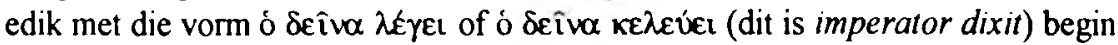
(Aune, 1990:199). Enige poging om die perikope in Openbaring 2 en 3 op formele gronde as epistels of een of ander briefvorm te tipeer, is dus ongeldig (Swete, 1906:23; Corsini, 1983:81; Kirby, 1988:199; Du Rand, 1990:268; Bailey \& Vander Broek, 1992:24, 205)

14 Vir voorbeelde van gemengde genres in die Bybel vergelyk Bailey en Vander Broek (1992:55-57) 


\section{Die verbondstruktuur}

Shea (1983) het die struktuur van die Hetitiese vasalverdrae en die perikope in Openbaring 2 en 3 vergelyk en tot die volgende gevolgtrekking gekom: "(I)t may be suggested that the pattern for the letters to the Seven Churches in Revelation is modelled after that of the older covenant formularity" (Shea, 1983:76). In die volgende paragrawe word Shea se standpunt belig en geëvalueer.

\subsection{Shea se bevinding}

Volgens Shea (1983:76-81) se navorsingsresultate korrespondeer die opbou van die Hetitiese vasalverdrae met dié van Openbaring 2 en 3 soos volg: (1) Inleiding (naam, titels, eienskappe en geslagsregister van koning) met die selfidentifikasie, (2) historiese proloog (vorige verbintenis tussen partye) met die oi $\delta \alpha$-uitspraak, (3) verdragsbepalings (verpligtinge van verdrag) met die opdragte (bekeer, terugdink, vashou, koop), (4) godelys (gode is getuies by verdragsluiting) met die gesagsuitspraak ("Elkeen wat kan hoor, moet luister na wat die Gees vir die gemeentes sê") en (5) vloek- en seënformule met die oorwinnaarsbelofte.

\subsection{Evaluering van Shea se bevinding}

- Dokumentklousule: Van Rooy (1977:257) wys daarop dat die Hetitiese vasalverdrae soms ook 'n dokumentklousule bevat het wat handel oor die verdragteks. Shea bring nie die dokumentklousule in sy vergelykende studie in berekening nie. In elke perikoop van Openbaring 2 en 3 kom ' $n$ skryfopdrag voor $(2: 1 \mathrm{a}, 8 \mathrm{a}, 12 \mathrm{a}, 18 \mathrm{a}, 3: 1 \mathrm{a}, 7 \mathrm{a}, 14 \mathrm{a})$ wat nie deur Shea verdiskonteer word nie. Die geheel van elke perikoop van Openbaring 2 en 3 word dus nie deur Shsa se ondersoek gedek nie. Hierdie skryfopdrag vind nie sy eweknie in die Hetitiese vasalverdrae se dokumentklousule nie

Inleiding by vasalverdrae: Indien die openingsverse van die perikope in Openbaring 2 en 3 (wat die skryfopdrag, die geadresseerdes en die selfidentifikasie bevat) as inleiding (in terme van ' $n$ vasalverdrag) beskou word, verwys Christus in Openbaring 2 en 3 na die 'grootkoning' en die gemeente na die 'vasal'. Die inleiding van die perikope in Openbaring 2 en 3 strook nie met dié van die Hetitiese vasalverdrae nie aangesien in die Hetitiese vasalverdrae die vasal se naam normaalweg nie in die inleiding voorkom nie (Mendenhall, 1954a:30, 37; 1954b: 48; Van Rooy, 1977:7).

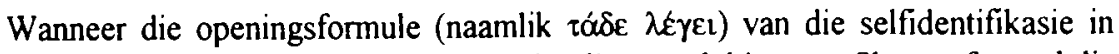
Openbaring 2 en 3 in ag geneem word by die vergelyking wat Shea tref, word die volgende gevind: 
* ' $n$ Tipiese inleidingsformule van die inleiding in die Hetitiese vasalverdrae is 'dit is die woorde van ...' (Goetze, 1931:202, 203; Van Rongen, 1966:65). Op die klank af korrespondeer dit met Shea (1983:76-80) se weergawe van

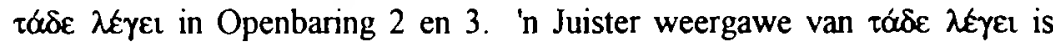
egter "[d]it sê Hy ..." (1933/53-Afrikaanse vertaling) of "[s]o sê Hy ..." (1983-Afrikaanse vertaling). Die formulering 'dit is die woorde van ...' in die Hetitiese vasalverdrae toon eerder ' $n$ ooreenkoms met Deuteronomium

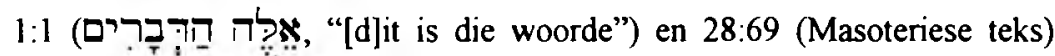

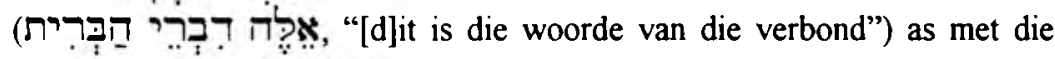

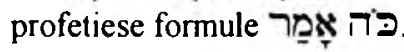

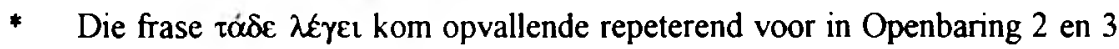
in dié gedagte-eenheid wat Shea sien as die eweknie van die Hetitiese

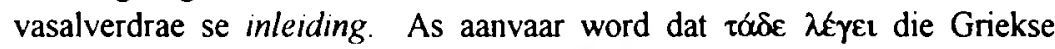

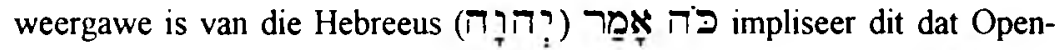
baring 2 en 3 nie taalkundig by Deuteronomium aansluit nie, dit wil sê by ' $n$

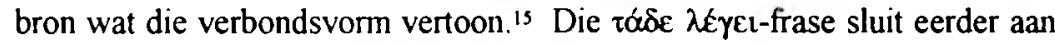

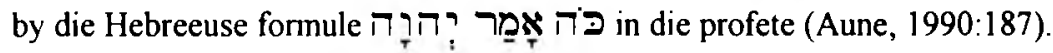

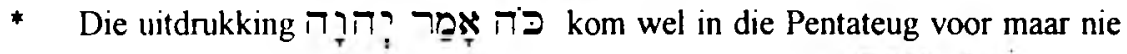

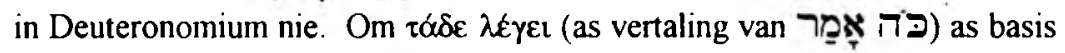
van vergelyking tussen Openbaring 2 en 3 en verbondsdokumente te gebruik, blyk dus ongeldig te wees.

Die $\tau \alpha \dot{\alpha} \delta \varepsilon \chi_{\varepsilon} \gamma \varepsilon t$-frases in Openbaring $2^{\circ}$ en 3 is nie die ekwiwalent van die inleiding van die Hetitiese vasalverdrae nie en het derhalwe ook nie die vorm van die inleiding van dié verdrae nie.

- Historiese proloog: Die historiese proloog van die Hetitiese vasalverdrae beskryf die betrekkinge wat daar tussen die 'grootkoning' en die 'vasal' in die verlede bestaan het (Mendenhall, 1954b:58-59; Van Rooy, 1977:8). Sommige oi $\delta \alpha$-frases in Openbaring 2 en 3 gee wel 'n weergawe van die verhouding tussen Christus en sy kerk $(2: 13,19 ; 3: 8)$, terwyl ander dit nie bevat nie $(2: 3,9 ; 3: 1,15)$. Inhoudelik is die oi $\delta \alpha$-uitsprake in Openbaring 2 en 3 nie 'n ekwiwalent van die historiese proloog van dié verdrae nie.

- Verdragsbepalings: In die Hetitiese vasalverdrae is honoreringspligte en positiewe vasalpligte opgeneem, waarvan die belangrikste die militêre verpligtinge was (Van Rooy, 1977:9-10). Letterlike militêre verpligtinge voor die deur van die kerk ontbreek in Openbaring 2 en 3 (vgl. honorerings-

15 Volgens Van Rooy (1977:279) is daar 'n nou aansluiting tussen Deuteronomium 1:1-28:69 en die Hetitiese vasalverdrae ten opsigte van struktuurelemente. 
pligte), alhoewel lojaliteit aan God (vgl. positiewe vasalpligte) van die kerk verwag en geïmpliseer word $(2: 5,10,16,20,3: 3,11,13)$. Die formele en inhoudelike ooreenkoms tussen die verdragsbepalings van die Hetitiese vasalverdrae en die opdragte aan die kerk in Openbaring 2 en 3 is baie vaag.

- Godelys: Die funksie van die sewevoudige gesagsuitsprake ("Elkeen wat kan hoor, moet luister na wat die Gees vir die gemeentes sê") in Openbaring 2 en 3 funksioneer waarskynlik nie om die Heilige Gees as getuie voor te stel op dieselfde vlak as die godelys in die vasalverdrae nie (Mendelhall, 1954b:60). Enroth (1990:608) het aangetoon dat die gesagsuitsprake in Openbaring 2 en 3 pareneties ${ }^{16}$ is. Dit blyk dus dat Shea se standpunt dat die gesagsuitsprake in Openbaring 2 en 3 die funksie van getuies het, ongeldig is.

- Vloek- en seënformule: Die vasalverdrae bevat vloek- en seënformules, terwyl die oorwinnaarsbelofies in Openbaring 2 en 3 slegs as seënformules geinterpreteer kan word. Die oorwinnaarsbeloftes kom dus slegs met een faset van die slotelement van die Hetitiese vasalverdrae ooreen.

- Algemene opmerking: Van Rooy (1977:277-278) het aangetoon dat die volgorde van die elemente asook die aantal elemente in verskillende verdrae (bv. die Hetitiese, Assiriese en Sefire-verdrae) verskil. Shea (1983:76) vergelyk die perikope in Openbaring 2 en 3 met 'n 'standaard'-verbondstruktuur terwyl die verbondsdokumente wat ter sprake is in werklikheid nie-eenvormig gekonstrueer is.

Die Hetitiese vasalverdrae het tot stand gekom in ongeveer 1500-1200 voor Christus en die kleitablette wat dié vasalverdrae bevat, is teen die begin van hierdie eeu in opgrawings ontdek (Gispen, 1974: 343; Van Rooy, 1977:2). Dit is dus onwaarskynlik - indien nie onmoontlik nie - dat Johannes hierdie dokumente ter insae gehad het.

\subsection{Gevolgtrekking}

Wat vorm betref, is daar enkele ooreenkomste tussen die perikope in Openbaring 2 en 3 en die buite-Bybelse vasalverdrae: sekere komponente van die buiteBybelse vasalverdrae kom wel in die perikope in Openbaring 2 en 3 voor. Daar is egter ook wesenlike verskille: sekere elemente van die buite-Bybelse vasalverdrae ontbreek in die perikope van Openbaring 2 en 3, byvoorbeeld die gode-

16 Enroth (1990:598-599) oorweeg dic esoteriese, parenetiese en noetiese funksie van die gesagsuitsprake in Openbaring 2 en 3 . Onder die esoteriese funksic word verstaan dat "this formula is a signal, the purpose of which is to indicate to both hearers and readers that a parable or a speech contains a deeper meaning" (Enroth, 1990.598) Die parenetiese funksie impliscer dat "(t)he hearer or reader must act and want to act according to what he understands" (Enroth, 1990:598). Die noetiese funksic kombineer die vorige twee. 
lyste en die dokumentklousule. Die inhoudelike verskille is egter van sodanige aard dat nie met stelligheid gesê kan word dat die perikope van Openbaring 2 en 3 op die patroon van buite-Bybelse vasalverdrae gekonstrueer is nie. Derhalwe blyk dit dat Shea nie oortuigend aangetoon het dat Openbaring 2 en 3 die patroon van die Hetitiese vasalverdrae vertoon nie.

\section{Samevatting}

In vergelyking met antieke geskrifte is die perikope in Openbaring 2 en 3 uniek wat vorm en funksie betref.

- Vorm: Openbaring 2 en 3 toon sterk trekke van die profetiese en apokaliptiese sowel as die koninklike edikgenre. Openbaring 2 en 3 bevat nie epistels nie en vertoon ook nie die vorm van die Hetitiese vasalverdrae nie.

- Inhoud: Openbaring 2 en 3 toon inhoudelik tematiese trekke van die OuTestamentiese profete.

- Funksie: Openbaring 2 en 3 funksioneer (soos Openbaring) as profesie sowel as apokalips, en elke perikoop in Openbaring 2 en 3 is troosboek, koningsboek en belofteboek (Op. 1:9; Coetzee, 1990:265-266).

Die bree formele ooreenkoms tussen die sewe perikope in Openbaring. 2 en 3 impliseer dat Jolıannes die struktuur van een of ander literêre vorm gevolg het 'n struktuur wat reeds bestaan het, of dat hy moontlik sekere elemente van 'n bestaande literêre vorm geimplementeer het.

Totdat uitsluitsel verkry is oor die spesifieke literêre vorn van die sewe perikope in Openbaring 2 en 3 word voorgestel dat nie die populêre term brief daarvoor gebruik word nie, maar eerder 'n term wat die vorm, inhoud en funksie daarvan verdiskonteer - 'n term soos profeties-apokaliptiese boodskap.

\section{Bibliografie}

AUNE, D E 1983. Prophecy in Early Christianity and the Ancient Mediterranean World Grand Rapids : Eerdmans Pulishing Company

AUNE, D E. 1986 The Apocalypse of John and the Problem of Genre Semeia, 36:65-96.

AUNE, D.E 1987 The New Testament and Its Literary Environment. Philadelphia : The Westminister Press.

AUNE, D.E. 1990. The Form and Function of the Proclamations to the Seven Churches. New Testament Studies, 36: 182-204

BAILEY, J.L \& VANDER BROEK, L.D 1992 Literary Forms of the New Testament Westminister Press : Louisville

COETZEE, J.C. 1990. Die prediking (teologie) van die Openbaring aan Johannes. (In Du Toit, A. B, red Handleiding by die Nuwe Testament. Band 6. Pretoria N.G. Kerkboekhandel p. 253-314)

COLLINS, A Y 1979. The Early Christian Apocalypses. Semeia, 14 60-122.

COLLINS, J J. 1979. Introduction: Towards the Morphology of a Genre Semeia, 14 1-20

CORSINI, E 1983. The Apocalypse Wilmington: Glazier 
DU RAND, J.A. 1990. Johannese perspektiewe. Deel 1. Inleiding tot die Johannese geskrifte. Pretoria : Orion.

ENROTH, A.M. 1990. The Hearing Formula in the Book of Revelation. New Testament Studies, 36:598-608.

GISPEN, W.H. 1974. Genesis. (Deel 1. Genesis 1:1-11:26.) Kampen : Kok

GOETZE, A. 1931. Hittite Treaties. (In Pritchard, J.B., ed. Ancient Near Eastern Texts Relating to the Old Testament. Princeton : Princeton University Press p. 201-206.)

GROENEWALD, E.P. 1986. Die Openbaring van Johannes. Kaapstad : NG Kerkuitgewers.

GROVE, AH. 1989. Die bose en die kerk volgens Openbaring 2 en 3. Bloemfontein Universiteit van die Oranje-Vrystaat. (M.A.-Verhandeling.)

GROVÉ, A. 1992. Die selfidentifikasie van Christus in Openbaring 2 en 3. Potchefstroom : PU vir CHO. (Ph.D.-Proefskrif.)

HELLHOLM, D. 1986 The Problem of Apocalyptic Genre and the Apocalypse of John. Semeia, 36:13-64.

KIRBY, J.T. 1988 The Rhetorical Situations of Revelation 1-3. New Testament Studies, 34: 197-207.

KITTEL, G 1969. $\lambda \hat{z} \gamma \omega$. (In Bromily, G.W., ed Theological Dictionary of the New Testament. Grand Rapids : Eerdmans Publishing Company. 4:91-143.)

LADD, G.E. 1972. A Commentary on the Revelation of John. Grand Rapids : Eerdmans.

LILJE, H. 1955. The Last Book of the Bible. Philadelphia : Muhlenberg Press.

MENDENHALL, G.E. 1954a. Ancient Oriental and Biblical Law. The Biblical Archaeologist, 17:26-46.

MENDENHALL, G.E 1954b. Covenant Forms in Israelite Tradition The Biblical Archaeologist, 17:50-76.

MOUNCE, R.H. 1980. The Book of Revelation. Grand Rapids : Eerdmans.

MULLER, U.B. 1983 Literarische und formgeschichtliche Bestimmung der Apokalypse des Johannes als einem Zeugnis frühchristlicher Apokalyptik ( $I n$ Hellholm, D ed Apocalyptism in the Mediterranean World and the Near East Tübingen : J.C.B. Mohr. p. 599620.)

MUSE, R.L. 1986 Revelation 2-3: A Critical Analysis of Seven Prophetic Messages Journal of the Evangelical Theological Society, 29:147-161

ROBERTS, J.H. 1988. A Letter to Seven Churches in Asia. (In Botha, J.E., De Villiers, P.G.R \& Engelbrecht, J. eds. Reading Revelation. Pretoria : J L van Schaik. p 17-35.)

SHEA, W.H 1983. The Covenantal Form of the Letters to the Seven Churches Andrews University Seminary Studies, 21:71-84

SWETE, H B 1906 The Apocalypse of John London : Macmillan

VAN DER WAAL, C. 1971. Openbaring van Jezus Christus. Groningen : Vuurbaak.

VAN RONGEN, G 1966. Zijn vast verbond Goes : Oosterbaan en Le Cointre.

VAN ROOY, HF. 1977. 'n Vergelyking van die struktuur van die buite-Bybelse staatsverdrae - met besondere aandag aan die Sefire-verdrae - met die struktuur van Deuteronomium. Potchefstroom : PU vir CHO. (D.Litt -Proefskrif.) 